\title{
A RE-ASSESSMENT OF THE GASTRIC LESION IN PERNICIOUS ANAEMIA
}

\author{
BY \\ H. A. MAGNUS \\ From the Department of Morbid Anatomy, King's College Hospital and Medical School, London
}

(RECEIVED FOR PUBLICATION JANUARY 9, 1958)

This short review is based on the Kettle Memorial Lecture for 1957. In order to understand the localization of the lesion found in the stomach in pernicious anaemia and the histological changes that occur in the affected mucosa it is necessary to remind ourselves of the normal anatomy and histology. Fig. 1 shows the average normal distribution of the body and pyloric mucosae in the human stomach. The body mucosa area occupies about the upper two-thirds of the stomach and contains the gastric glands proper. The pyloric mucosa area occupies about the lower third of the stomach and contains the pyloric glands. These mucosal areas are not sharply defined from each other and at the borderline the glands of one mix with the glands of the other. Along the lesser curvature the body glands usually meet the pyloric glands somewhere in the region of the incisura angularis. Along the greater curvature the body glands extend further into the pyloric region and may almost reach the pylorus. The pyloric region, therefore, is commonly triangular in shape with its apex at the incisura angularis. However, the distribution of the pyloric mucosa along the lesser curvature is very variable and, on occasion, it may extend right up to the oesophagus as a narrow band. This observation may well be of importance in the understanding of the topography of chronic ulcers in the stomach.

The surface epithelium of the body and pyloric mucosae has everywhere the same structure. It is composed of tall, regular columnar cells with basal nuclei and clear, transparent, only faintly granular cytoplasm. Cells with striated borders and goblet cells are not found amongst the cells of the surface epithelium in normal stomachs and only occur when islets of intestinal epithelium are present (Magnus, 1937).

The body mucosa (Fig. 2) contains the gastric glands, simple branched tubules opening into the gastric pits which, in the body mucosa, are shallow. The tubules are tightly packed together and arranged perpendicular to the surface of the mucosa. The blind ends are club-shaped and sometimes divide into two or three branches. These glands contain four types of cell: (1) Neck chief cells, (2) body chief cells, (3) parietal cells, and (4) argentaffine cells.

The neck chief cells are identical with the cells lining the cardiac and pyloric glands. They are

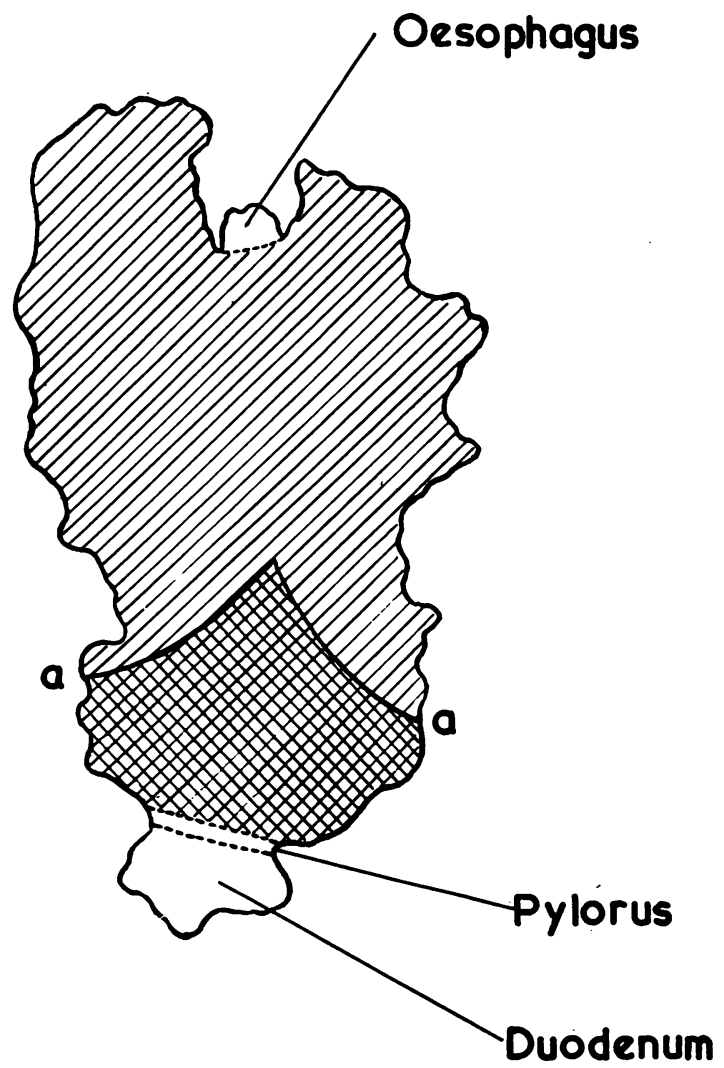

FIG. 1.-Diagram of the stomach opened along the greater curvature. Line a-a represents the demarcation between $1 / / / / / / /$, body and $\ 2 \times$ pyloric mucosae. 
mucin-producing columnar cells which line the upper, narrower part of the glands. The body chief cells produce the pepsin of the gastric juice which is present in the cells in the form of a granular precursor. They line the lumina of the tubules below the neck chief cells. The parietal cells produce the acid of the gastric juice and are scattered singly, internal to the body chief cells, but are most numerous at the necks of the tubules where they. are interspersed between the neck chief cells. They are spherical or triangular in shape and the cell cytoplasm stains readily with acid dyes. Very occasionally an argentaffine cell is present at the bases of the tubules.

The pyloric mucosa (Fig. 3) is also composed of glands with simple, branched tubules, but the tubules are coiled and the glands open into gastric pits which extend much deeper inwards and are frequently branched. The pyloric glands are lined by mucin-producing cells only. Here, also, an occasional argentaffine cell may be found.

In both the body and pyloric mucosae the glands are separated by scanty connective tissue consisting of a delicate network of collagenous and reticulum fibres in which cells are sparse. These consist of occasional fibroblasts and reticuloendothelial cells and scattered lymphocytes, plasma cells, and eosinophils. In normal mucosa lymphocytes may occasionally form small lymph follicles, especially in the pyloric mucosa.

Before considering the changes that may be found in the gastric mucosa in anaemia it would be as well to review briefly the history of the association of a lesion of the stomach with the clinical condition we call pernicious anaemia. This extends over nearly 100 years, for it was Austin Flint (1860) who first suggested the possibility of such a relationship. Samuel Fenwick (1880) made the first pathological investigation of the stomach in pernicious anaemia. He recorded four cases of " essential anaemia," in all of which there was atrophy of the stomach and especially of the gastric mucosa. Nothnagel (1879), almost at the same time, described similar findings, but in all these cases the stomachs were unfixed and the histology uncertain. Faber and Bloch (1900, 1904) published the first reliable histological description of changes in the stomach based on well-fixed material. They examined the stomachs from eight patients dying from pernicious anaemia and found a diffuse gastritis in every case. They made no menton of any localization of the gastritis to any particular part of the stomach. From 1900 to 1938 it was generally accepted that a "diffuse chronic gastritis" was present in the stomach in pernicious anaemia. Wallgren (192325) and Brown (1934) confirmed Faber and $\overrightarrow{\bar{B}}$ Bloch's findings but, for the most part, on unfixed material. Magnus and Ungley (1938) published the results of an investigation of the stomachs of seven cases of pernicious anaemia in which the $\vec{\Phi}$ stomachs were fixed soon after death. They $\frac{\Omega}{0}$ showed that, in these cases, the lesion was con- $\infty$ fined to the body mucosa area of the stomach and $\overrightarrow{0}$ that the pyloric mucosa area was unaffected. $\overrightarrow{\vec{H}}$ Meulengracht (1937), at the first meeting of the $\tilde{\omega}^{\circ}$ German Haematological Society held at Munster, described similar findings which were exactly the reverse of what he had expected from his work on $\overrightarrow{\vec{A}}$ the stomach of the pig. Cox (1943) confirmed these results and Magnus (1952) recorded the same $\underset{0}{0}$ findings in a further 10 cases.

It would be as well to consider here the nature of the lesion which these workers described and $\check{E}$ the tentative conclusions which could be made, at that time, from their observations. The macro- $\vec{\theta}$ scopic changes seen in the stomach were of usually striking. The upper two-thirds of the stomach. that is, the region of the body mucosa, showed a severe atrophy so that this area was reduced to the thinness of parch-o ment. At the junction of the body with the $\frac{0}{\mathbb{Q}}$ pyloric mucosa, however, there was a transition, $\varrho$ usually abrupt, to the normal thickness of the $\overrightarrow{\overrightarrow{0}}$ stomach wall and this was maintained throughout 3 the whole of the pyloric antrum. Histological examination confirmed the naked-eye distribution of the atrophy. In the body mucosa area there was a severe atrophy involving all the coats of the stomach wall (Fig. 4) and it was clear that the 3 . parchment-like thinness observed macroscopically 8 was not due to mucosal atrophy alone. In the mucosa (Fig. 5) all that remained was the surface epithelium and a few scattered glands lined by mucus-producing cells whilst the specialized body음 chief cells and parietal cells had disappeared. Yet there was a complete absence of fibrosis, cellularo infiltration, obliterative endarteritis, or other 0 evidence of past inflammation, and there was a N corresponding absence of fibrosis in the submucosa and subserosa. The muscle coat showed atrophy but here also there was an absence of fibrosis. In $\frac{\text { C }}{\mathbb{D}}$ many stomachs examined large areas of intestinal@ epithelium were present in the atrophic body mucosa. The significance of this finding will be discussed later.

The main conclusions which could be drawn from this work were as follows:

(a) The lesion that occurred in the stomach in pernicious anaemia was not the end-result of ang 


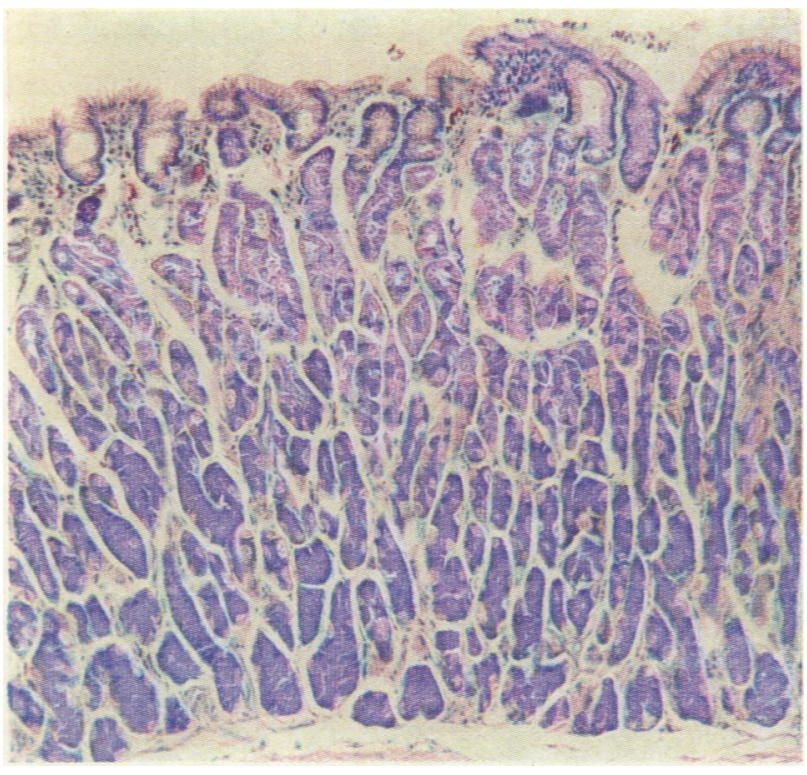

FIG. 2.-Normal body mucosa (Lillie's azure A-cosin B, $\times 95$ ).

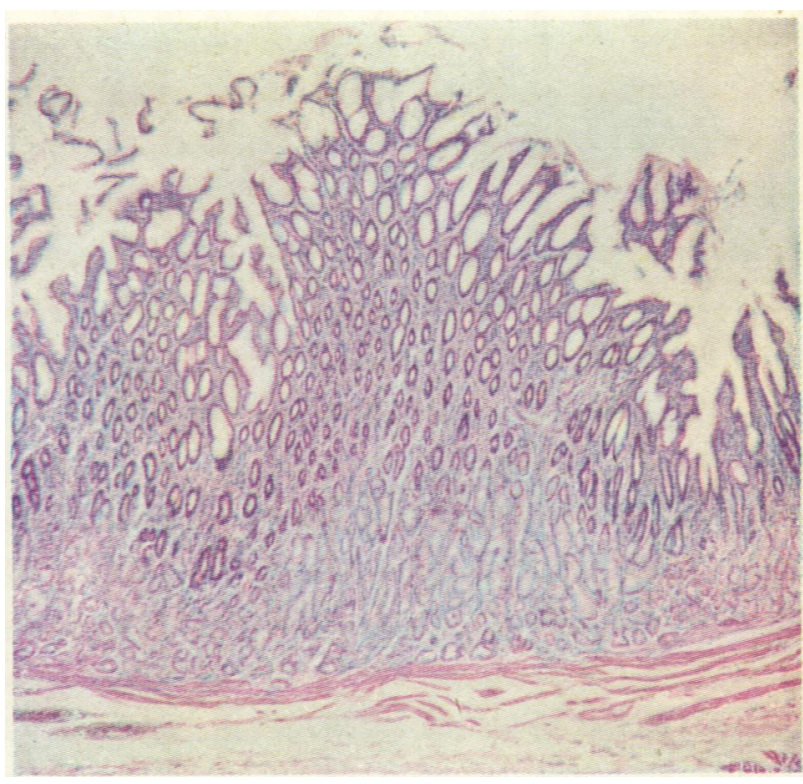

FIG. 3.-Normal pyloric mucosa (haematoxylin and eosin, $\times 30$ ).

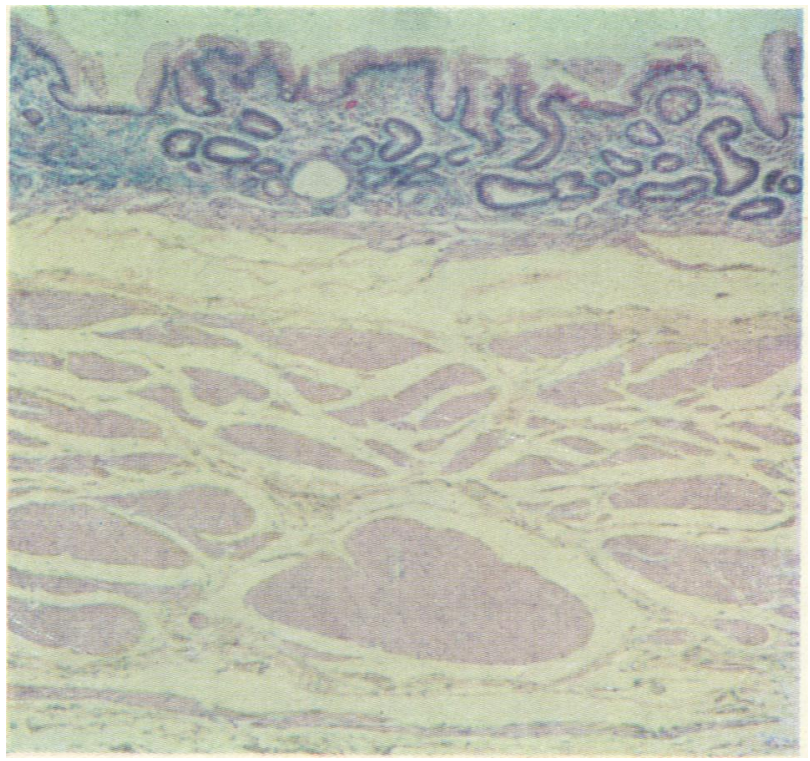

Fig. 4.-Severe atrophy involving all coats of the stomach wall (haematoxylin and eosin, $\times 50$ ). 


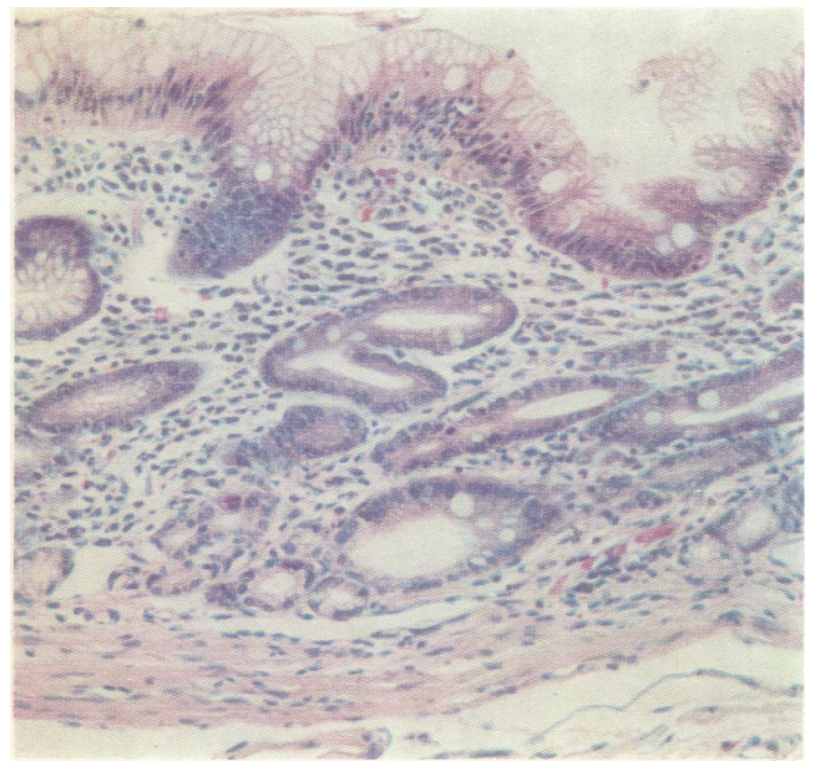

FIG. 5.-The body mucosa is completely replaced by simple glands lined by mucus-producing cells. There is no evidence of a past or recent inflammatory reaction (haematoxylin and eosin, $\times 200$ ).

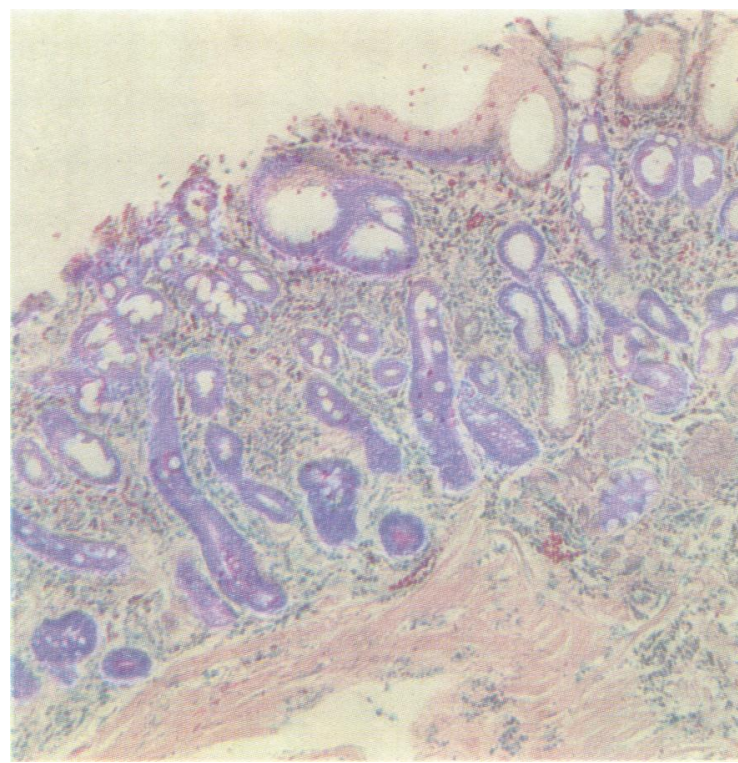

FIG. 6.--Severe atrophic gastritis with intestinal metaplasia. Note the persistence of recognizable body mucosa to the left of the pictured (Lillie's azure $A-\operatorname{cosin} B, \times 45$ ).

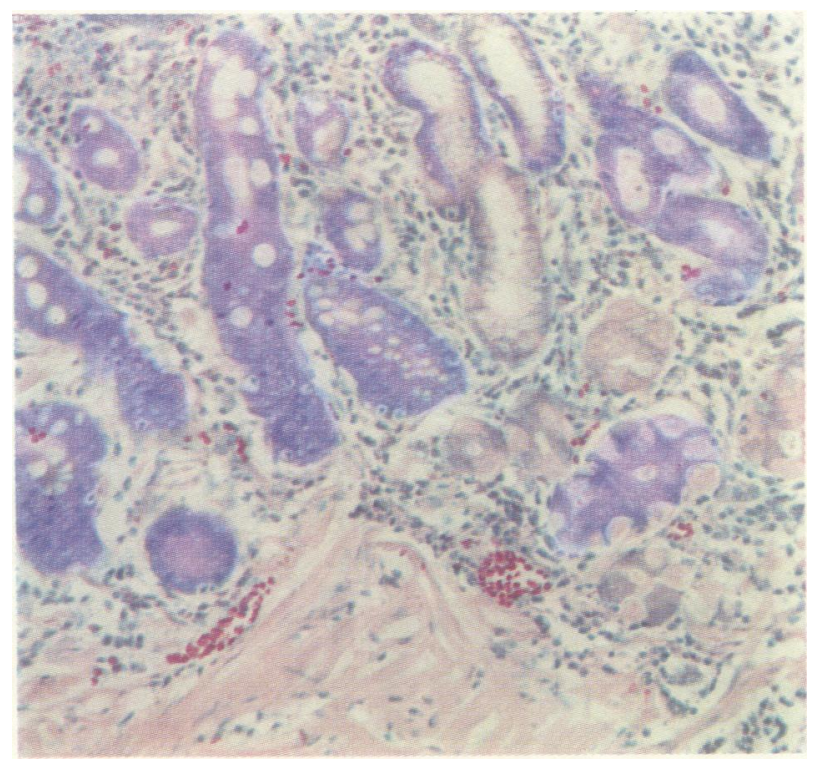


inflammatory gastritis but appeared to be the result of some endocrine or nutritional deficiency or might even be congenital in origin.

(b) At this time this lesion had not been seen in any other condition and most workers believed that it was specific for pernicious anaemia.

With the introduction, in 1949, of the flexible gastric biopsy tube by Wood and his colleagues at the Walter and Eliza Hall Institute of Medical Research, Melbourne, a milestone was reached in the investigation of the changes that might occur in the stomach, not only in pernicious anaemia, but also in other anaemias, notably iron-deficiency anaemia. A method was available for studying the state of the gastric mucosa in life which was not only safe but could be repeated several times on the same patient. One had no longer to wait for many years to collect a small amount of wellfixed material from dead patients but could gather, in a relatively short time, more material and information than one individual could collect previously in a lifetime. The investigation of patients with pernicious anaemia and iron-deficiency anaemia over the last eight years has produced new evidence which must now be considered and as a result of which some of our previously held views must be modified.

In 1955 Joske, Finckh, and Wood reviewed 1,000 gastric biopsies performed on 623 subjects, including 100 cases of pernicious anaemia or subacute combined degeneration of the cord or both. Their findings in these cases are shown in Table I. All these patients had histamine-fast achlorhydria. From Table I it can be seen that the gastric lesion,

TABLE I

RESULTS OF GASTRIC BIOPSY ON 100 CASES OF PERNICIOUS ANAEMIA OR SUBACUTE COMBINED DEGENERATION OF THE CORD OR BOTH (JOSKE, FINCKH, AND WOOD, 1955)

\begin{tabular}{|c|c|}
\hline Number of Cases & State of Gastric Mucosa \\
\hline $\begin{array}{r}9 \\
16 \\
35 \\
40\end{array}$ & $\begin{array}{l}\text { Superficial gastritis with atrophy } \\
\text { Atrophic gastrit is } \\
\text { Severe atrophic gastritis } \\
\text { Gastric atrophy }\end{array}$ \\
\hline 100 & \\
\hline
\end{tabular}

previously described as occurring in pernicious anaemia, was only present in 40 out of the 100 cases investigated. In 60 cases only varying degrees of what, from the description given, would appear to be inflammatory atrophic gastritis were present. There was a widespread cellular infiltrate of the substantia propria with atrophy of tubules. Survival of body chief and parietal cells varied with the severity of the lesion, but usually a few survived even in the severest form of atrophic gastritis. Within the last two $2 \mathbf{F}$ years the writer has seen a stomach from a man, aged 74, who had had pernicious anaemia for seven years. This showed similar changes. Instead of the severe non-inflammatory atrophy of the body mucosa with complete disappearance of the specialized cells there was a severe atrophic gastritis with persistence of foci of body chief and parietal cells (Figs. 6 and 7).

It would seem, therefore, that the lesion in the stomach in pernicious anaemia may, in many cases, be less severe than complete gastric atrophy and in the nature of an inflammatory atrophic gastritis. Palmer (1954), in a revaluation of the pathology of gastritis based on gastric biopsy material, goes so far as to state that he found no evidence that a distinction could be made between "chronic atrophic gastritis" and "mucosal atrophy" in the stomach in pernicious anaemia or that glandular atrophy may develop without chronic inflammation.

Most observers would feel to-day, however, that in adult pernicious anaemia two types of gastric lesion may be found, one an atrophic gastritis of varying severity and the other a gastric atrophy involving all coats of the stomach wall. What relationship, if any, do these two lesions have to each other? Witts (1956) believes that they are separate entities with possibly different aetiologies. Whilst this may be so, it seems to the writer, having re-examined his own material and had the opportunity of examining other workers' material obtained by gastric biopsy, that they represent stages in the same pathological process. Such a conception has already been put forward by Davidson and Markson (1955).

How is it that, in the post-mortem material examined before the introduction of the flexible gastric biopsy tube, only gastric atrophy in its severest form was seen and involving all coats of the stomach wall ? There seem to be two possible explanations. First each observer only saw a relatively small number of cases, and secondly all the patients were dead either from untreated pernicious anaemia or from some other disease, having had pernicious anaemia for many years. That the gastric lesion in pernicious anaemia is the end-result of some inflammatory or degenerative process would also explain why it has never been seen in childhood: it cannot be congenital in origin. The possibility that the lesion is the result of an inflammatory process does not necessarily mean that its cause must be exogenous. Recently papers have appeared reporting the results of investigations of the stomach in irondeficiency anaemia which may well throw light on 
the aetiology of the gastric lesion in pernicious anaemia. Davidson and Markson (1955) and Badenoch, Evans, and Richards (1957) have investigated the state of the gastric mucosa in irondeficiency anaemia by gastric biopsy. In the series of cases in both papers a very high percentage of patients showed an abnormal gastric mucosa. Many had severe chronic atrophic gastritis and some complete gastric atrophy. Both sets of authors produce cogent arguments and evidence to support the view that the gastric changes are the result of the iron deficiency and not the cause of it. This conception opens up a new approach to the problem of the part played by the stomach in the pathogenesis of pernicious anaemia. The views put forward by these workers, however, have been challenged in a recently published paper by Lees and Rosenthal (1958), who investigated 21 patients with iron-deficiency anaemia. These patients all had gastric biopsies, their blood was restored to normal by iron therapy, and in 19 cases gastric biopsy was repeated in a year. In no case was there any improvement in the state of the gastric mucosa, and in some the changes had progressed. It was concluded, therefore, that the gastric mucosal lesions were not due to iron deficiency but preceded and favoured its development.

There can be no doubt that gastric atrophy of the severest degree can occur without the clinical picture of pernicious anaemia. As has been seen it occurs in iron-deficiency anaemia and also, as in Joske et al.'s (1955) series, without any anaemia at all. Doig, Motteram, Weiden, and Wood (1950) describe its presence in a perfectly healthy medical student who had histamine-fast achlorhydria. Of special interest is the fact that his maternal grandmother had pernicious anaemia. Why do these patients not have the clinical picture of pernicious anaemia ? It is known that if the whole stomach is removed in man it takes from four to six years for pernicious anaemia to develop. Badenoch et al. (1957) showed in a series of cases of irondeficiency anaemia that some patients had impaired absorption of labelled $\mathbf{B}_{12}$, and in four out of six patients who were given $50 \mathrm{mg}$. of intrinsic factor with labelled $\mathbf{B}_{12}$ there was a significant increase of absorption of the vitamin. Pedersen, Lund, Ohlsen, and Kristensen (1957) estimated the incidence of mild vitamin $B_{12}$ deficiency in elderly patients with histamine-refractory achlorhydria. Forty-six patients aged 50 or more had several studies of sternal marrow and seven were shown to have partial or incipient megaloblastic erythropoiesis. Unfor- tunately no gastric biopsies were performed. Mollin, Booth, and Baker (1957) record an investigation into the absorption of labelled vitamin $B_{12}$ in control subjects, in Addisonian pernicious anaemia, and in the malabsorption syndrome. They found five patients with histamine-fast achlorhydria who did not have pernicious anaemia yet gastric biopsy showed gastric atrophy or atrophic gastritis. These patients absorbed as little labelled vitamin $B_{12}$ as did patients with pernicious anaemia, but they had no clinical or other pathological evidence of this disease. All this surely points to the hypothesis that, if the manufacture of the intrinsic factor or its precursors is gradually reduced, the development of the gastric lesion and a subclinical deficiency of vitamin $B_{12}$ run hand in hand.

That severe gastric atrophy may be present for years before clinical pernicious anaemia develops is shown by the case recorded by Robertson, Wood, and Joske (1955). This was a man aged 65 who had a long history of dyspepsia. Gastric biopsies showed complete gastric atrophy yet his peripheral blood and bone marrow were normal. Five years later he returned with typical pernicious anaemia and subacute combined degeneration of the cord.

There is ample pathological evidence to show that after adequate therapy the gastric mucosa in pernicious anaemia shows no recovery. This is what one would expect if the cause of the lesion is an absence of intrinsic factor or its precursor. In the writer's material four patients had been adequately treated for from five to 13 years and all showed severe gastric atrophy. Doig and Wood (1950), Finckh and Wood (1953), Joske et al. (1955), Badenoch et al. (1957), and others have all produced overwhelming evidence that the gastric mucosa does not recover after prolonged therapy.

A fascinating aspect of the problem is revealed by the study of the literature on juvenile pernicious anaemia. Many workers dismiss out of hand the fact that true pernicious anaemia can occur in childhood or adolescence, believing that all these cases can be explained by the association of a megaloblastic anaemia with sprue or a similar syndrome. This is not the case, and after the application of the strictest criteria one is left with about 20 cases of true juvenile pernicious anaemia. One of the most interesting points about these cases is that many have free $\mathrm{HCl}$ in the gastric juice, a fact that would make many refuse to accept them as pernicious anaemia out of hand, but this would be unwise. Mollin, Baker, and Doniach (1955) record the case of a young man, aged 18 
years at the time of the report, who had suffered from pernicious anaemia from the age of 13 months. His parents were first cousins. The patient secreted normal amounts of acid and pepsin in the gastric juice which, however, was deficient in intrinsic factor. A gastric biopsy showed perfectly normal body mucosa. The patient's father also suffered from pernicious anaemia with achylia gastrica and a gastric biopsy showed a severe atrophic gastritis with some parietal and body chief cells still recognizable, i.e., gastric atrophy was not yet complete. The study of these rare cases of true juvenile pernicious anaemia indicates, as Benjamin (1948) has pointed out, that they may be explained by a congenital absence of intrinsic factor or its precursor. The presence in some of free $\mathrm{HCl}$ with a normal mucosa suggests that it may take many years for the gastric lesion to develop, and supports the conception that a subclinical state of vitamin $B_{12}$ deficiency may be present for a long time before the clinical picture of pernicious anaemia is seen.

The fact that there is often a strong family history in many cases of pernicious anaemia has been known for many years. One of the best investigations into the subject has been carried out by Mosbech (1953) in Copenhagen. He investigated approximately 3,000 relatives of 234 patients with pernicious anaemia and found that the disease occurred about 20 times more frequently amongst them than in a control series. Its distribution amongst various categories of relatives appeared to be compatible with recessive inheritance with a reduced rate of manifestation. McIntyre, Sachs, Krevans, and Conley (1956) have shown that the family members of patients with pernicious anaemia not infrequently show subnormal absorption of radioactive $B_{12}$. Surely these results also point to an inborn chemical error as the basic cause of both pernicious anaemia and the gastric lesion with which it is associated.

It is generally agreed, but not proved, that it is the neck chief cells near the surface of the body mucosa of the stomach which secrete the intrinsic factor, about the chemical nature of which little is known. Marmion, Gardner, Saint, and Stubbe (1953) agree that there is good evidence that the intrinsic factor is a mucoprotein, but not one that is reduced by a receptor-destroying enzyme, and it differs therefore in its properties from a gonadotrophin and mucoprotein derived from respiratory tract cells. The complexity of the work is well seen in a paper by Glass, Stephanson, Rich, and Laughton (1957), who investigated intrinsic factor activity of human gastric juice after fractionation by continuous electrophoresis on paper curtains. Intrinsic factor activity was so widespread throughout the fractions that they suggest that intrinsic factor is, perhaps, not a substance but only a reactive group, present on one or more mucoproteins endowed with intrinsic factor activity.

For the last 20 years it has been suggested from time to time that there is an increased incidence of gastric cancer in pernicious anaemia. There are two ways of considering figures in relation to this problem. First the number of people of both sexes who have pernicious anaemia and develop gastric cancer may be studied. Table II shows

TABLE II

INCIDENCE OF GASTRIC CANCER IN PATIENTS WITH PERNICIOUS ANAEMIA

\begin{tabular}{c|c|c|c|c}
\hline Source & $\begin{array}{c}\text { No. of } \\
\text { Patients } \\
\text { (Both } \\
\text { Sexes) }\end{array}$ & $\begin{array}{c}\text { Period } \\
\text { of } \\
\text { Time } \\
\text { (years) }\end{array}$ & $\begin{array}{c}\text { No. of } \\
\text { Cases of } \\
\text { Gastric } \\
\text { Cancer }\end{array}$ & $\begin{array}{c}\text { Approximate } \\
\text { No. of Cases } \\
\text { per 1,000 } \\
\text { Patient-Years }\end{array}$ \\
$\begin{array}{l}\text { Wilkinson (1956) } \\
\text { Davidson (1957) }\end{array}$ & 2,211 & 28 & 39 & $1 \cdot 0-2 \cdot 0$ \\
726 & 10 & 7 & 1.9 \\
\hline
\end{tabular}

the figures for the incidence of gastric cancer in two large pernicious anaemia clinics in this country. As large numbers of patients are being followed up for varying periods of time the last column in the table shows the approximate number of cases per 1,000 patient-years which, under these circumstances, is the most convenient way of measuring the rate of occurrence of a disease. Whilst there are no reliable comparable figures for the frequency of cases of gastric cancer in the population as a whole, one can make a reasonable guess in the following way. In 1955 there were 7,000 deaths in England and Wales from cancer of the stomach in both sexes between the ages of 40 and 70 . There must be perhaps between 8,000 and 10,000 new cases per year to account for this number of deaths. The population of the country in this age group is approximately $16,000,000$ and, if incidence is defined as meaning new cases per 1,000 patient-years, then the figure for cancer of the stomach is 0.5 to 0.6 . It would appear, therefore, that the chance of acquiring cancer of the stomach may be two or three times as great in a patient with pernicious anaemia as in the population as a whole.

Secondly the mortality from gastric cancer in patients with pernicious anaemia can be considered and can be compared with the mortality from gastric cancer in a population of the same age group. Table III shows figures from three different sources, and the proportion of deaths due to gastric cancer are in close agreement, showing 
TABLE III

MORTALITY DUE TO GASTRIC CANCER IN PATIENTS WITH PERNICIOUS ANAEMIA

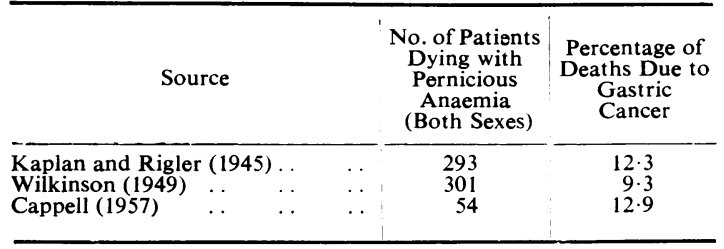

an average of $11.5 \%$. In $1955,3.7 \%$ of all deaths in England and Wales in people of both sexes between the ages of 40 and 70 were due to gastric cancer. There would seem to be agreement, therefore, between the figures obtained in two different ways from which it may be concluded that the chances of a patient with pernicious anaemia developing cancer of the stomach are about three times greater than might be expected in the population as a whole. The situation has been well summed up by Mosbech and Videbaek (1950), who, as a result of a follow-up of 301 patients being treated for pernicious anaemia over a 20year period, concluded that there was no increased mortality in this disease compared with the population as a whole. Although the total death rate from cancer in all organs did not appear to be excessive, the number of patients with gastric cancer greatly exceeded the expected figure and there was the same increase for both sexes-the longer you live with pernicious anaemia the more likely are you to develop gastric cancer.

Why should patients dying with pernicious anaemia have this increased incidence of gastric cancer which, according to Mosbech (1953), also occurs amongst their relatives without pernicious anaemia? The usually accepted explanation is that the two diseases may have an inherited genetic background. This may be so, but it is possible that there is another explanation. In the writer's material it has been extremely common to find that most of the body area of the stomach, the site of the gastric lesion, has been replaced by intestinal epithelium and this observation has been confirmed by others. It is, in fact, most unusual to see such extensive intestinal metaplasia in the body area of the stomach except in pernicious anaemia. Morson (1955a, b, and c) in several papers has published the results of a painstaking investigation into the incidence and distribution of intestinal epithelium in the stomach in simple ulcer, in cancer, and in duodenal ulcer. He has shown that about $30 \%$ of gastric cancers arise from areas of intestinal metaplasia which should be regarded, therefore, as a precancerous state. The natural deduction from this work is that cancer of the stomach should be much commoner in the fundic area in cases of pernicious anaemia than when it arises without this association. According to Schell, Dockerty, and Comfort (1954), this is indeed the case. They investigated 94 cases of pernicious anaemia with gastric cancer and found that in $58.3 \%$ it was in the fundic or cardiac regions and in $14.6 \%$ there were either separate tumours in the pyloric and fundic areas or an extensive tumour involved both areas. These figures have so far not been confirmed by other observers, some of whom, indeed, have published figures the exact opposite, but the largest number of patients under observation was 14 , so that there can be no comparison. Reports from other clinics on this important question of the siting of gastric cancer in cases of pernicious anaemia must be awaited.

To summarize, what is the position to-day with regard to the gastric lesion in pernicious anaemia? Twenty years ago it was believed to be a specific lesion and not the end-result of an atrophic gastritis. It would now seem that both these conclusions have to be modified and the new evidence suggests that the basic lesion in pernicious anaemia does not lie in the stomach. The changes in the gastric mucosa may well be endogenous in origin and due to the fact that the intrinsic factor or its precursors are necessary for the maintenance of its normal structure and function. The basic lesion would appear to be an inherited chemical defect. perhaps expressed by the inability of certain cells of the gastric mucosa to manufacture an essential enzyme.

My thanks are due to Sir Stanley Davidson for kindly allowing me to use unpublished figures in Table II and to Professor D. F. Cappell for unpublished figures in Table III. I am indebted to $\mathrm{Mr}$. M. P. Curwen, medical statistician to St. Bartholomew's Hospital and King's College Hospital Medical School, for advice on the figures for the incidence of gastric cancer in pernicious anaemia. Mr. George Harwood is responsible for the photomicrographs.

\section{REFERENCES}

Badenoch, J., Evans, J. R., and Richards, W. C. D. (1957). Brit. J. Haemat., 3, 175.

Benjamin, B. (1948). Amer. J. Dis. Child., 75, 143.

Brown, M. R. (1934). New Engl. J. Med., $210,473$.

Cappell, D. F. (1957). Personal communication.

Cox, A. J. (1943). Amer. J. Path., 19, 491.

Davidson, L. S. P. (1957). Personal communication.

Davidson, W. M. B., and Markson, J. L. (1955). Lancet, 2, 639

Doig, R. K., Motteram, R., Weiden, S., and Wood, I. J. (1950) Ibid., 1, 948.

- and Wood, I. J. (1950). Med. J. Aust., 2, 565.

Faber, K., and Bloch, C. E. (1900). Z. klin. Med., 40, 98.

Faber, K., (1904). Arch. Verdau.-Kr., 10, 1.

Fenwick, S. (1880). On Atrophy of the Stomach and on the Nervou Affections of the Digestive Organs. J. \& A. Churchill, London. 
Finckh, E. S., and Wood, I. J. (1953). Gastroenterology, 25, 48.

Flint, A. (1860). Amer. med. Times, 1, 181.

Glass, G. B. J., Stephanson, L., Rich, M., and Laughton, R. W. (1957). Brit. J. Haemat., 3, 401.

Joske, R. A., Finckh, E. S., and Wood, I. J. (1955). Quart. J. Med., $24,269$.

Kaplan, H. S., and Rigler, L. G. (1945). Amer. J. med. Sci., $209,339$.

Lees, R., and Rosenthal, F. D. (1958). Quart. J. Med., $27,19$.

McIntyre, P. A., Sachs, M. V., Krevans, J. R., and Conley, C. L. (1956). Arch. intern. Med., 98, 541.

Magnus, H. A. (1937). J. Path. Bact., 44, 389.

- (1952). Modern Trends in Gastroenterology. Butterworth, London.

and Ungley, C. C. (1938). Lancet, 1, 420.

Marmion, B. P., Gardner, H. J., Saint, E. G., and Stubbe, J. L. (1953). Ibid., 1, 273.

Meulengracht, E. (1937). Ibid., 1, 1404.

Mollin, D. L., Baker, S. J., and Doniach, I. (1955). Brit. J. Haemat., $1,278$.
Mollin, D. L., Booth, C. C., and Baker, S. J. (1957). Ibid., 3, 412. Morson, B. C. (1955a). Brit. J. Cancer, 9, 377. (1955b). Ibid., 9, 365.

(1955c). Ibid., 9,550

Mosbech, J. (1953). Heredity in Pernicious Anaemia. Ejnar Munksgaard, Copenhagen. and Videbaek, A. (1950). Brit. med. J., 2, 390.

Nothnagel, H. (1879). Dtsch. Arch. klin. Med., 24, 353.

Palmer, E. D. (1954). Medicine (Baltimore), 33, 199.

Pedersen, J., Lund, J., Ohlsen, A. S., and Kristensen, H. P. O. (1957). Lancet, $1,448$.

Robertson, E. G., Wood, I. J., and Joske, R. A. (1955). Ibid., 2, 69. Schell, R. F., Dockerty, M. B., and Comfort, M. W. (1954). Surg. Gynec. Obstet., 98, 710.

Wallgren, T. (1923-25). Arb. path. Inst. Univ. Helsingf. n. F., 3, 275. Wilkinson, J. F. (1949). Lancet, 1, 249, 291, and 336. (1956). Ibid., $2,977$.

Witts, L. J. (1956). Anaemia and the Alimentary Tract. Royal College of Physicians of Edinburgh Publications No. 7. 